\title{
The Potential of Bilateral Trade Between Egypt And Nile Basin Countries: A Gravity Model Approach
}

Doi: 10.29023/alanyaakademik.338645

\author{
Mohamed MOHAMED \\ Department of Agricultural Economics, Fayoum University, Egypt \\ Sayed SALAH \\ Department of Agricultural Economics, Fayoum University, Egypt \\ Ayman SHELABY \\ Department of Agricultural Economics, Fayoum University, Egypt +201004547558 , \\ ayman.shelaby@fayoum.edu.eg
}

\section{Keywords: \\ Egypt agricultural exports \\ Bilateral trade \\ Gravity model \\ Nile Basin}

Received: 18.09 .2017

Accepted: 27.02.2018

\begin{abstract}
This research aims at determining the factors affecting the agricultural bilateral trade flows of Egypt with the Nile Basin countries using the gravity model. Basic and Augmented models have been estimated for both Egyptian agricultural exports and imports. The growth of Egyptian exports to the Nile Basin countries is affected by GDP of both sides. There's a great chance for Egypt to increase the exports to Nile Basin countries by increasing GDP. Distance has a negative impact due to the poor and insufficient transportation infrastructure of Nile Basin countries. Which give more attention to the development of roads and Nile shipping to increase bilateral trade between Egypt and Nile basin countries.
\end{abstract}

\section{INTRODUCTION}

Nile River is considered the longest rivers in the world. It crosses the borders of 11 African countries; Uganda, Kenya, Ethiopia, the Democratic Republic of Congo, Tanzania, Burundi, Rwanda, Eritrea, South Sudan, Sudan and Egypt (Faten, 2013). As the Nile is the only source of surface water for Egypt, Nile Basin countries are considered of a national and strategic importance for Egypt. Thus, there are trends to foster bilateral trade between Egypt and the African countries in general and Nile basin countries in particular.

However, the volume of trade exchange between Egypt and the Nile Basin countries is noted as unsatisfactory in comparison with the strategic importance of these countries in Egypt. Egypt's total exports to the Nile basin countries amounted to 1.01 billion US dollars at an annual average of the period 2010-2015, and represented about $3.7 \%$ of the total value of Egyptian exports. Imports from these countries reached about 412 million dollars at an annual average during the same period, and represented only $0.62 \%$ of the total value of Egyptian imports from the world (International Trade Centre, 2017).

Despite the strategic importance of Nile basin countries for Egypt and being a promising market of Egyptian exports and imports. Moreover, the majority of these countries besides Egypt, are members of COMESA agreement which facilitates the African intra-trade, the 
total volume of trade exchange is still limited to $1.52 \%$ of the total Egypt's trade with the world.

In this respect, this paper uses the gravity model approach to determine the factors that influencing trade flows between Egypt and the Nile basin countries through investigating; an overview of the Nile basin Countries Intra-trade.

\section{NILE BASIN COUNTRIES INTRA-TRADE OVERVIEW}

\subsection{Egypt's Bilateral Trade with Nile Basin Countries}

The value of Egyptian exports to Nile basin countries was steadily increasing during the period 2001-2015 as shown in table 1. It's also shown that the relative importance of Egyptian exports to Nile basin countries to the total Egyptian exports increased from $1.51 \%$ in 2001 to $4.89 \%$ in 2015. As shown from growth equations in table 2, Egyptian exports to Nile basin countries increases by an annual growth of 22.5\% during the period of 2001-2015.

The value of Egyptian imports from Nile basin countries has increased from 0.17 billion US dollars in 2001 to 0.36 billion US dollars in 2015 as shown in table 2. It's also shown that the relative importance of Egyptian imports from Nile basin countries of the total Egyptian imports has decreased from $1.33 \%$ in 2001 to $0.48 \%$ in 2015 . As it is shown from growth equations in table 2, Egyptian imports from Nile basin countries increases by an annual growth rate of $11.5 \%$ during the period of 2001-2015.

Table 1. Development of Egypt's bilateral trade with Nile basin countries 2001-2015, (in billion US dollars)

\begin{tabular}{|c|c|c|c|c|c|c|}
\hline Year & $\begin{array}{c}\text { Egypt's } \\
\text { Total } \\
\text { Exports }\end{array}$ & $\begin{array}{c}\text { Egypt's } \\
\text { Total } \\
\text { Imports }\end{array}$ & $\begin{array}{c}\text { Egypt's } \\
\text { Exports to } \\
\text { Nile Basin } \\
\text { Countries }\end{array}$ & $\begin{array}{c}\text { \% of } \\
\text { Egypt's } \\
\text { Total } \\
\text { Exports }\end{array}$ & $\begin{array}{c}\text { Egypt's } \\
\text { Imports } \\
\text { from Nile } \\
\text { Basin } \\
\text { Countries }\end{array}$ & $\begin{array}{c}\text { \% of } \\
\text { Egypt's } \\
\text { Total } \\
\text { Imports }\end{array}$ \\
\hline $\mathbf{2 0 0 1}$ & 4.14 & 12.72 & 0.06 & 1.51 & 0.17 & 1.33 \\
\hline $\mathbf{2 0 0 2}$ & 4.66 & 12.50 & 0.06 & 1.27 & 0.21 & 1.67 \\
\hline $\mathbf{2 0 0 3}$ & 6.16 & 10.89 & 0.11 & 1.86 & 0.12 & 1.09 \\
\hline $\mathbf{2 0 0 4}$ & 7.68 & 12.84 & 0.14 & 1.89 & 0.09 & 0.67 \\
\hline $\mathbf{2 0 0 5}$ & 10.65 & 19.81 & 0.27 & 2.52 & 0.09 & 0.47 \\
\hline $\mathbf{2 0 0 6}$ & 13.72 & 20.59 & 0.26 & 1.93 & 0.09 & 0.43 \\
\hline $\mathbf{2 0 0 7}$ & 16.17 & 27.03 & 0.27 & 1.67 & 0.10 & 0.38 \\
\hline $\mathbf{2 0 0 8}$ & 25.97 & 52.75 & 0.78 & 3.01 & 0.27 & 0.51 \\
\hline $\mathbf{2 0 0 9}$ & 24.18 & 44.91 & 0.84 & 3.46 & 0.27 & 0.60 \\
\hline $\mathbf{2 0 1 0}$ & 26.33 & 53.00 & 1.00 & 3.79 & 0.27 & 0.51 \\
\hline $\mathbf{2 0 1 1}$ & 31.58 & 62.28 & 1.03 & 3.27 & 0.41 & 0.66 \\
\hline $\mathbf{2 0 1 2}$ & 29.42 & 69.87 & 0.98 & 3.34 & 0.46 & 0.66 \\
\hline $\mathbf{2 0 1 3}$ & 28.78 & 66.67 & 1.05 & 3.65 & 0.43 & 0.65 \\
\hline $\mathbf{2 0 1 4}$ & 26.81 & 71.34 & 0.92 & 3.43 & 0.54 & 0.76 \\
\hline $\mathbf{2 0 1 5}$ & 21.97 & 74.36 & 1.07 & 4.89 & 0.36 & 0.48 \\
\hline Average & $\mathbf{1 8 . 5 5}$ & $\mathbf{4 0 . 7 7}$ & $\mathbf{0 . 5 9}$ & $\mathbf{2 . 7 7}$ & $\mathbf{0 . 2 6}$ & $\mathbf{0 . 7 2}$ \\
\hline
\end{tabular}

Source: www.trademap.org 
Table 2. Growth equations of Egypt's bilateral trade with Nile Basin countries during the period 2001-2015

\begin{tabular}{|l|c|c|c|c|}
\hline \multicolumn{1}{|c|}{ Item } & Equation & $\mathbf{T}$ & $\mathbf{R}^{\mathbf{2}}$ & $\mathbf{F}$ \\
\hline $\begin{array}{l}\text { Egypt's Exports to Nile Basin } \\
\text { Countries }\end{array}$ & $\mathbf{Y = 4 . 1 7} \mathbf{x}^{\mathbf{0 . 2 2 5}}$ & $(9.2)^{* *}$ & 0.86 & $(85)^{* *}$ \\
\hline $\begin{array}{l}\text { Egypt's Imports from Nile Basin } \\
\text { Countries }\end{array}$ & $\mathbf{Y = 4 . 4 6 \mathbf { ~ } \mathbf { 0 . 1 1 5 }}$ & $(4.4)^{* *}$ & 0.57 & $(19.4)^{* *}$ \\
\hline
\end{tabular}

** Significant at level $(0.01)$

Source: calculated from table 1.

\subsection{Nile Basin Countries Intra- Trade}

Common boarders potentially increase bilateral trade between Nile basin countries. Table 3 shows that about $45 \%, 30 \%$ and $28 \%$ of Uganda, Kenya and Rwanda's total export, respectively, go to neighboring Nile basin countries. As for imports, it's found that about $23 \%, 19 \%$ and $14 \%$ of Rwanda, Burundi and Uganda's total imports sourced from Nile basin countries. As for Egypt, it is noticed that its bilateral trade with Nile Basin countries is lower compared to its total trade with the world. Egyptian exports to Nile Basin countries represent about $3.6 \%$ of Egypt's total exports at an annual average of the period 2010-2015, while imports are as low as $0.58 \%$ of the total Egyptian imports from the world during the same period.

Noticeably, there is a relatively strong trade relation between some of Nile Basin countries, especially those with common borders such as Sudan, Uganda, Kenya and Congo. The presence of road throughout these countries facilitates the flow of products through the borders. The total value of intra-exports of Nile basin countries is about $9.6 \%$ of its exports to the world during the average period of 2010-2015, while the total value of its intra-imports represents only about $4.4 \%$ of its imports from the world during the same period.

\section{RESEARCH METHODOLOGY}

\subsection{Theoretical Review}

Apparently, the gravity model takes its name from the law of gravity of Newton, which is due to the attraction of two bodies to their mass and negatively to the distance between them. Tinbergen (1962) and Linnemann (1966) were the first to explain the flow of international trade based on the physical principles of gravity where the two opposite forces determine the volume of bilateral trade between two countries or economic blocs.

Anderson et al (2003) indicated the factors affecting the volume of bilateral trade as following; the level of economic activity, income, and the barriers to trade. The latter include in particular transportation costs, trade policies, uncertainty, cultural differences, geographical characteristics, limited overlap in consumer preference schemes, regulatory bottlenecks, and common borders.

Various combinations of macroeconomic variables, such as GDP and population with geographic distance, are powerful predictors of trade potentials. Hence, gravity equations use these variables and have been used extensively in the empirical literature on international trade (Bayoumi et al, 2007).

The model is widely used in the empirical literature to evaluate the determinants of bilateral trade. It explains a trade-related dependent variable, by the combination of macroeconomic variables, such as country size, income, exchange rates, prices etc., for both countries. 
Moreover, indicators of transportation costs between the two countries and more general market access variables are commonly added (Said et al, 2014).

Table 3. Trade matrix of Nile Basin countries intra- trade as average of the period of 2010-2015, (in million US dollars)

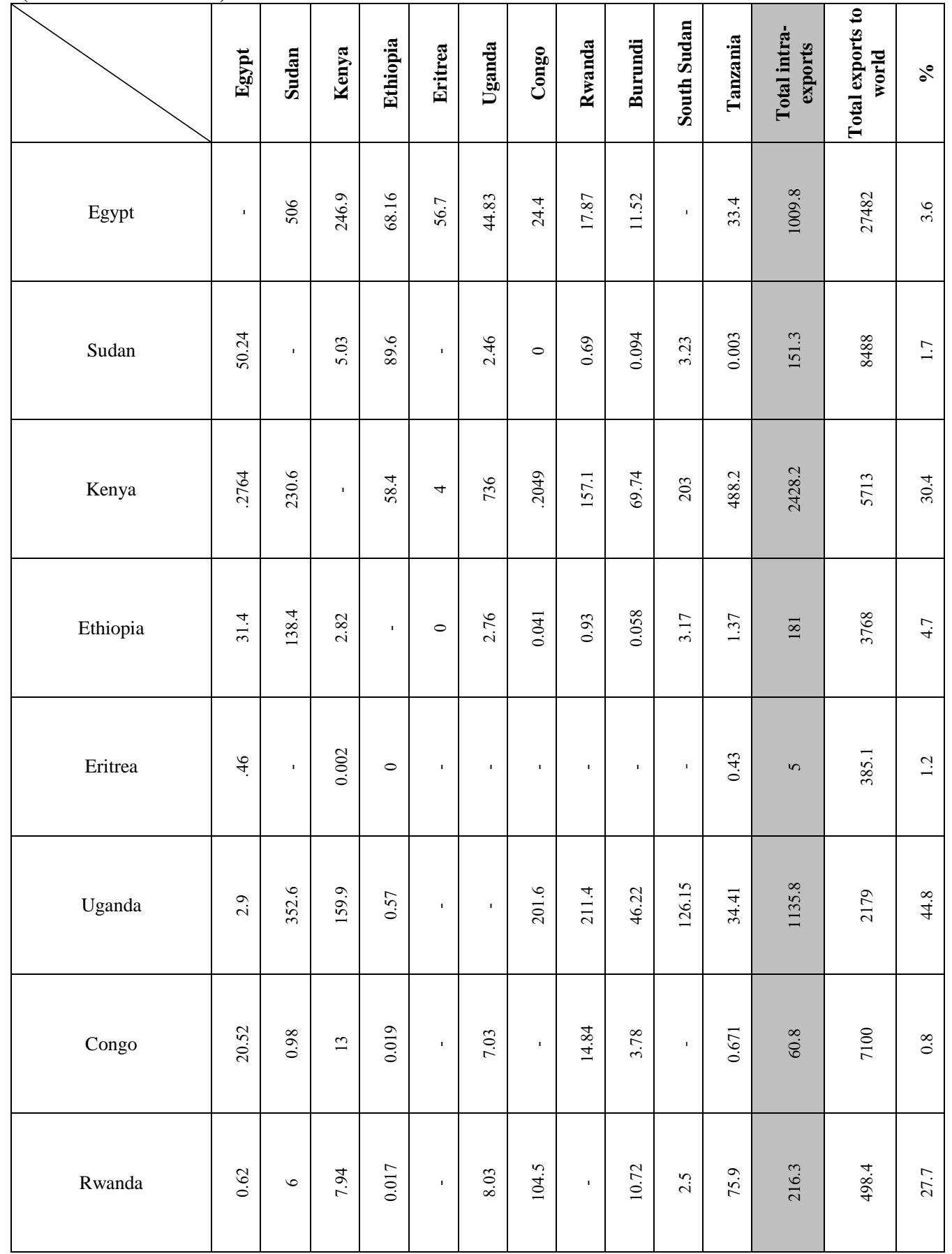




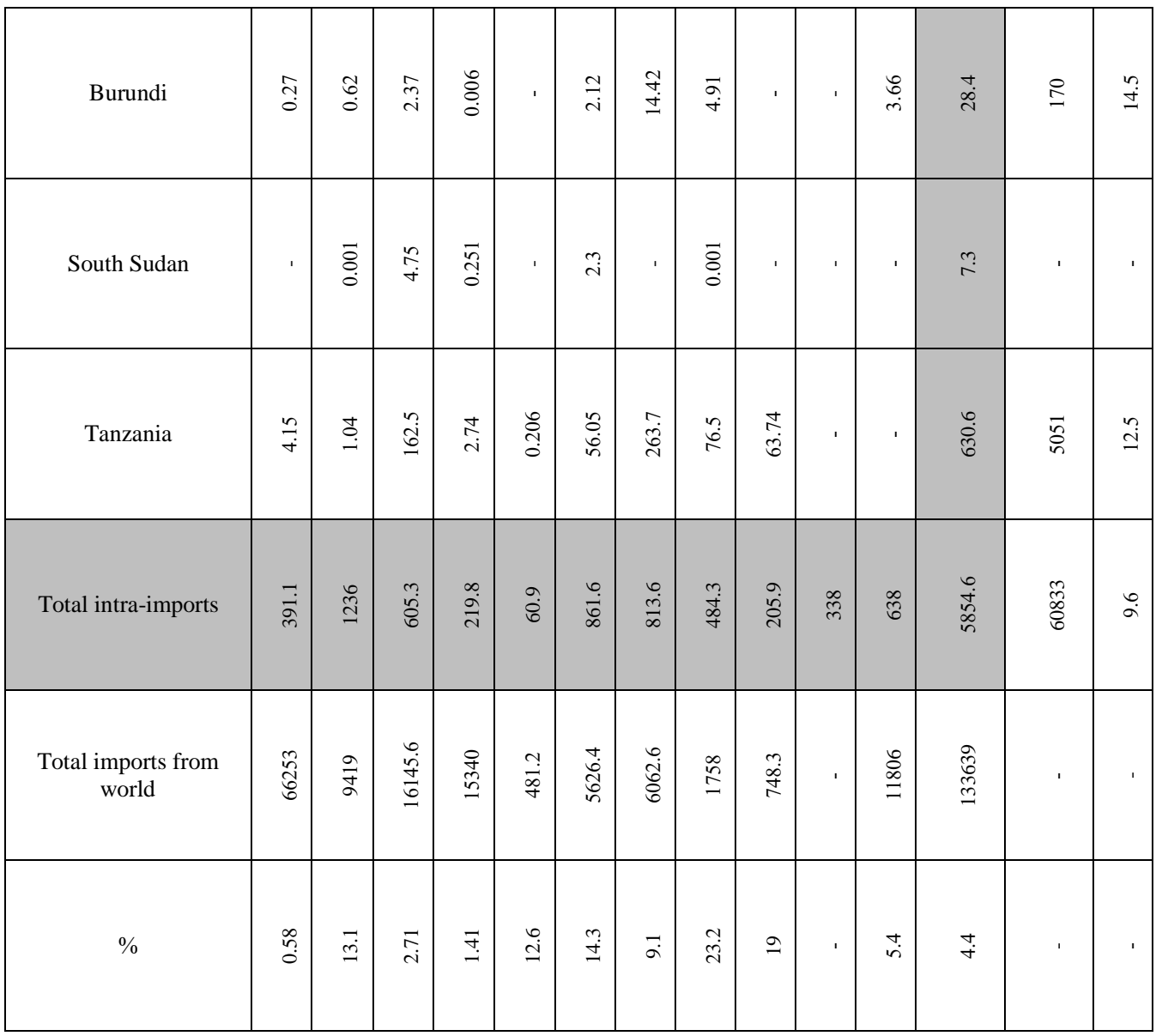

Source: www.trademap.org

\subsection{Model Specification}

Gravity Model is estimated using the time series data regression. The gravity model depends on Newton's theory of gravity that the attractive force between two objects is positively related with their masses and negatively related to the square of distance (Anderson, 2016). Based on Newton's theory of gravity, a similar functional relation that explains the flow of international trade can be proposed as the following (Tinbergen, 1962):

Fij $=$ G Mi $\alpha \operatorname{Mj} \beta / \operatorname{Dij} \theta$

Where,

Fij: Volume of trade between two countries $\mathrm{i}$ and $\mathrm{j}$.

$\operatorname{Mi}(j)$ : Relevant economic size of country $i(j)$.

Dij: Distance between the countries $\mathrm{i}$ and $\mathrm{j}$. 
The flow of trade between two countries is positively related to the GDP of two countries and negatively related to the geographical distance between capital of those two countries or major cities. The model can be expressed using the following exponential equation:

Yij $=\beta 0$ GDPi $\beta 1$ GDPj $\beta 2$ Distij- $\beta 3$ (2)

Where,

Yij: Volume of trade between two countries.

GDPi and GDPj: Gross Domestic Product of the countries i and j.

Distij: Distance between the countries $\mathrm{i}$ and $\mathrm{j}$.

This exponential equation can be converted into a function. By taking the logarithm of the two sides, it can be converted into a double logarithmic function as shown in equation (2)

$\ln Y i j=\beta 0+\beta 1 \operatorname{lnGDPi}+\beta 2 \operatorname{lnGDPj}-\beta 3 \ln D i s t i j+£ i j$

Where $£$ ij represents the random error. This equation is called the Basic Gravity Model (BGM). The population variable of the two countries within the model is added into the equation (3) and it is called the Augmented Gravity Model (AGM) as follows:

$\ln Y i j=\beta 0+\beta 1 \operatorname{lnGDPi}+\beta 2 \operatorname{lnGDPj}+\beta 3 \ln P c i+\beta 4 \ln P c j-\beta 5 \ln \operatorname{listij}+£ i j(4)$

In this paper, beside the Basic Gravity Model (BGM) and the Augmented Gravity Model (AGM), variables to be used such as Foreign Direct Investment (FDI) and dummy variables (Djt) such as common borders, common language and trade agreements so the equation will be as follows:

$\ln Y i j=\beta 0+\beta 1 \ln G D P i+\beta 2 \operatorname{lnGDPj}+\beta 3 \ln P c i+\beta 4 \ln P c j-\beta 5 \ln D i s t i j+\beta 6 \ln I i+\beta 7 \ln \mathrm{Ij}+\operatorname{Dij}+$ $£ i j(5)$

Where,

i: Egypt

j: Nile basin countries

Yij: Trade exchange whether exports or imports between country $\mathrm{i}$ and country $\mathrm{j}$.

GDPi and GDPj: GDP of countries $i$ and $j$.

PCi and PCj: Per capita GDP of countries $i$ and $j$.

Ii and Ij: Foreign direct investment in countries $\mathrm{i}$ and $\mathrm{j}$.

Distij: Geographical distance between the capital of two countries or the most important commercial cities.

Dij: Dummy variable represent (having common borders, language and trade agreements).

$£$ ij: Random error.

B0, 1, 2, n: Constants of proportionality.

Ln: natural logarithm. 


\subsection{Variables Included in the Model}

The data included in the model are time series from 2001 to 2015. Data for total exports and imports were obtained from Trade statistics of the international trade center UNCTAD/WTO (ITC). Data for Gross Domestic Product GDP, per capita GDP, and Foreign Direct Investment FDI were obtained from World Development Indicators database (WDI) of the World Bank. Distances between countries were obtained from the Distance website (www.distancefromto.net/countries.php) and presence of common borders was obtained from Google Maps website (www.maps.google.com).

\section{FINDINGS}

Data for the variables included in the model has been processed four times and generated four models. The first one is estimated on the basis of Egypt as an exporting country towards the 9 Nile Basin partners; Tanzania, Rwanda, Burundi, Democratic Republic of Congo, Kenya, Uganda, Ethiopia, Eritrea, Sudan (North + South), where it is consisted of the Basic Gravity Model (BGM) and the Augmented Gravity Model (AGM). The other one is estimated on the basis of Egypt as an importing country from the same countries, where also it is consisted of the (BGM) and the (AGM). The model includes the GDP variables of Egypt and the Nile Basin countries, the geographical distance between Egypt and each of Nile basin countries, the volume of foreign investments in Egypt and the Nile Basin countries (FDI), and some dummy variables such as the existence of common borders, common language and the presence of countries within COMESA. Dummy variable takes value 1 in case of the existence of common borders, common language and the presence of countries within COMESA and value 0 in case of not. The Stepwise Regression model was used to determine the most significant variables and to exclude those non-significant.

\subsection{Exports' Model}

\subsubsection{Basic Gravity Model (BGM)}

The outcomes shown in Table 4 indicate that the most significant variables affecting Egypt's exports to the Nile basin countries are GDP and geographical distance between Egypt and these countries, where the rest of the variables were excluded from the Stepwise regression for non-significant effect. The results indicate that the increase of Egypt GDP (GDPi) by $10 \%$ leads to an increase of $17.5 \%$ in the Egyptian exports to the Nile Basin countries. The increase of GDPj for Nile Basin countries by $10 \%$ leads to an increase of $9.9 \%$ in the Egyptian exports to these countries. The results also showed that the increase of geographical distance (Distij) between Egypt and these countries by $10 \%$ leads to a decrease of Egyptian exports by $24.8 \%$. The significant variables explain about $81.5 \%$ of the changes occurring in Egyptian exports as the R2 of the model is 0.815 , and the model is statistically significant at a significant level of 0.01 according to $\mathrm{F}$ test.

Table 4. Estimated Results of Exports' Gravity Model

\begin{tabular}{|c|c|c|}
\hline \multirow[b]{2}{*}{ Variables } & \multicolumn{2}{|c|}{ Exports' Gravity Model } \\
\hline & Basic Gravity Model & Augmented Gravity Model \\
\hline Equation & $\begin{array}{l}\mathrm{Ln} \mathrm{Y}_{\mathrm{i}}=11.13+1.75 \ln \mathrm{GDP}_{\mathrm{i}}+0.99 \\
\ln \mathrm{GDP}_{\mathrm{j}}-2.48 \ln \text { Dist }_{\mathrm{ij}}\end{array}$ & $\begin{array}{l}\ln \mathrm{Y}_{\mathrm{i}}=-7.75+1.3 \ln \mathrm{PC}_{\mathrm{i}}+2.1 \ln \mathrm{PC}_{\mathrm{j}} \\
-1.5 \ln \text { Dist }_{\mathrm{ij}}\end{array}$ \\
\hline GDP $_{\mathbf{i}}$ & $\begin{aligned} 1.75 \\
\mathrm{~T}=(9.7) * * \\
\end{aligned}$ & - \\
\hline $\mathbf{G D P}_{\mathbf{j}}$ & 0.99 & - \\
\hline
\end{tabular}




\begin{tabular}{|c|c|c|}
\hline & $\mathrm{T}=(14.3)^{* *}$ & \\
\hline Distance & -2.48 & -1.5 \\
& $\mathrm{~T}=(-9.9)^{* *}$ & $\mathrm{~T}=(-4.98)^{* *}$ \\
\hline $\begin{array}{c}\text { Per Capita } \\
\text { GDP }_{\mathbf{i}}\end{array}$ & - & 1.3 \\
\hline $\begin{array}{c}\text { Per Capita } \\
\text { GDP }_{\mathbf{j}}\end{array}$ & - & $\mathrm{T}=(4.5)^{* *}$ \\
\hline $\mathbf{R}^{\mathbf{2}}$ & 0.815 & 2.1 \\
\hline $\mathbf{F}$ & $(198.2)^{* *}$ & $\mathrm{~T}=(11.1)^{* *}$ \\
\hline $\mathbf{N}$ & 135 & 0.754 \\
\hline
\end{tabular}

Source: Results obtained through processing of data using SPSS 18

\subsubsection{Augmented Gravity Model (AGM)}

As it is shown in Table (4), the most significant variables affecting Egypt's exports to the Nile basin countries are Per Capita GDP and geographical distance between Egypt and these countries, where the rest of the variables were excluded from the Stepwise regression for nonsignificant effect. The results indicate that the increase of Per Capita GDPi in Egypt by $10 \%$ leads to an increase of $13 \%$ in the Egyptian exports to these countries, the increase of Per capita GDPj for Nile Basin countries by $10 \%$ leads to an increase of $21 \%$ in the Egyptian exports to these countries and the increase of geographical distance Distij between Egypt and these countries by $10 \%$ leads to a decrease of Egyptian exports by $15 \%$. The significant variables explain about $75.4 \%$ of the changes occurring in Egyptian exports as the R2 of the model is 0.754 , and the model is statistically significant at a significant level of 0.01 according to $\mathrm{F}$ test.

\subsection{Imports' Model}

\subsubsection{Basic Gravity Model (BGM)}

The results in Table (5) indicate that the factors affecting Egypt's imports from the Nile Basin countries are the GDPj of the Nile Basin countries, the geographical distance between Egypt and these countries, and the existence of the common borders with these countries. The rest of the variables entered in the model were excluded from Stepwise regression because their nonsignificant effect. The results indicate that the increase of GDPj of the Nile Basin countries by $10 \%$ leads to an increase of Egyptian imports from these countries by $27 \%$, while the results showed that the increase of the geographical distance (Distij) between Egypt and these countries by $10 \%$ leads to a decrease of Egyptian imports by $51 \%$, and that the existence of a common border between Egypt and these countries reduces imports by $36 \%$. It is illogical to note that the existence of a common border has a negative sign, this can be explained that the most Egyptian imports from the Nile Basin countries, with the exception of Sudan that has a common border with Egypt, freight whether by ships or aircrafts as is the case of Tanzania, Kenya and Uganda. The significant variables explain about $59 \%$ of the changes occurring in Egyptian imports as the R2 of the model is 0.59 , and the model is statistically significant at 0.01 levels according to $\mathrm{F}$ test.

Table 5. Estimated Results of Imports' Gravity Model

\begin{tabular}{|c|c|c|}
\hline \multirow{2}{*}{ Variables } & \multicolumn{2}{|c|}{ Imports' Gravity Model } \\
\cline { 2 - 3 } & Basic Gravity Model & Augmented Gravity Model \\
\hline \multirow{2}{*}{ Equation } & $\ln \mathrm{yj}=35+2.7 \ln \mathrm{GDP}_{\mathrm{j}}-5.1 \ln$ Dist $_{\mathrm{ij}}-$ & $\ln \mathrm{Y}_{\mathrm{j}}=-24.14+4 \ln \mathrm{PC}_{\mathrm{j}}$ \\
\hline \multirow{2}{*}{ GDPi } & - & - \\
\hline
\end{tabular}




\begin{tabular}{|c|c|c|}
\hline GDPj & $\begin{array}{c}2.7 \\
\mathrm{~T}=(12.78)^{* *}\end{array}$ & - \\
\hline Distanceij & $\begin{array}{c}-5.1 \\
\mathrm{~T}=(-5.1)^{* *}\end{array}$ & - \\
\hline Borderij & -3.6 & - \\
\hline $\begin{array}{c}\text { Per capita } \\
\text { GDPi }\end{array}$ & $\mathrm{T}=(-3.1)^{* *}$ & 4 \\
\hline $\begin{array}{c}\text { Per capita } \\
\text { GDPj }\end{array}$ & - & $\mathrm{T}=(9.54)^{* *}$ \\
\hline $\mathbf{R 2}$ & - & 0.402 \\
\hline $\mathbf{F}$ & 0.591 & $(91)^{* *}$ \\
\hline $\mathbf{N}$ & $(65.5)^{* *}$ & 135 \\
\hline
\end{tabular}

Source: Results obtained through processing of data using SPSS 18

\subsubsection{Augmented Gravity Model (AGM)}

As it is shown in Table (5), the factors affecting Egypt's imports from the Nile Basin countries are only the Per Capita GDP of the Nile Basin countries. The rest of the variables entered in the model were excluded from Stepwise regression because their non-significant effect. The results indicate that the increase of the Per Capita GDP of the Nile Basin countries by $10 \%$ leads to an increase of Egyptian imports from these countries by $40 \%$. The significant variables explain about $40 \%$ of the changes occurring in Egyptian imports as the R2 of the model is 0.40 , and the model is statistically significant at 0.01 levels according to $\mathrm{F}$ test.

\section{DISCUSSION AND POLICY IMPLICATION}

According to the results showed by Exports' gravity model; the growth of Egyptian exports to Nile Basin countries is expected to be affected by both Egypt and Nile Basin countries' GDP, the value of the coefficient on log of GDPi (1.75), while it is (0.99) for GDPj. That's mean There's a great chance for Egypt to increase the total exports to Nile Basin countries by increasing the GDP, which is a factor that can be handled internally.

Distance between Egypt and Nile Basin countries has a negative sign for the coefficient on log of Distij in both Exports and imports' gravity model, which can be explained that the main transportation system used in exporting and importing between Egypt and Nile Basin countries is poor and insufficient where the majority of Nile Basin countries are suffering from the absence of infrastructure that capable of cross-border trade. Which give more attention to the development of roads and Nile shipping to increase bilateral trade between Egypt and Nile basin countries.

The FDI in Egypt and Nile Basin countries is excluded from Stepwise regression because their non-significant effect. It has no impact on the intra-trade between Egypt and Nile Basin countries.

Borders according to the basic gravity model of imports have a negative sign for the coefficient. Although it is expected that the existence of common borders between Egypt and Nile Basin countries would increase the intra trade (common borders are expected to have a positive sign). However, this might be explained that the most of Egyptian imports from Nile Basin countries are transferred using air cargo or sea cargo.

Many studies have been investigating the determinants of the Egyptian bilateral trade with the Arab countries, EU countries, and COMESA countries. The results of the study are consistent 
with most of other related studies. Ata (2010) refers to the positive impact of GDP in Egypt and other countries and the negative impact of distance on the Egyptian exports to COMESA. Shehata (2011) and Molouk (2012) indicated that there is a positive impact for GDP on the Egyptian agricultural exports to COMESA and the Arab countries.

\section{CONCLUSION AND RECOMMENDATION}

Although the strategic importance of Nile basin countries for Egypt and being a promising market for Egyptian exports and imports. Nevertheless, intra-trade between Egypt and these countries still unsatisfactory in comparison with Egypt's foreign trade with world. It is indicated that Egypt can increase its intra- trade with Nile basin countries by enhancing Egyptian GDP.

It is also implied that short distances between Cairo and other capital cities of Nile basin countries positively increase the Egyptian exports and imports. The basic gravity model of imports has shown unexpected result of the impact of having a common border, this means that the government of Egypt and Nile basin countries too, must give much attention to invest in roads between Egypt and the neighboring countries such as Sudan that can be taken as a crossing gate for exports and imports with Nile basin countries.

\section{REFERENCES}

ANDERSON, J. E. \& WINCOOP, E.V. (2003). Gravity with gravitas: a solution to the border puzzle. American Economic Review, 93(1), 170-192.

ANDERSON, J. E. (2016). The Gravity Model of Economic Interaction. Boston College and NBER. https://www2.bc.edu/james-anderson/GravityModel.pdf

ATA, S. (2010). Estimating the Economic Impacts of trade Exchange between Egypt and COMESA using Gravity Model, 18th Conference of Agricultural Economists, Egyptian-African Economic and Agricultural Cooperation, Egyptian Society for Agricultural Economics, 13-14 October 2010.

BAYOUMI, T. \& EICHENGREEN, B. (2007). Is regionalism simply a diversion? evidence from the evolution of the EC and EFTA. In T. Ito \& A. O. Krueger (Eds.), Regionalism versus Multilateral Trade Arrangements (pp. 141-168). Chicago, NBEREASE Volume 6, University of Chicago Press. http://www.nber.org/papers/w5283.pdf

FATEN S. A. et al., Agricultural production and water indicators in the Nile basin countries. Zagazig Journal of Agricultural Research, Vol 40, No. 4, 2013, pp. 791-797.

International Trade Centre UNCTAD/WTO (ITC), Trade statistics for international business development, Trade map www.trademap.org, 2017.

LINNEMANN, H. (1966). An econometric study of international trade flows (Master Thesis), Netherlands School of Economics, Netherlands. Available from Google Books.

MOLOUK, O. (2012). Two-way trade of agricultural commodities in Arab countries. Egyptian Journal of Agricultural Economics, 22 (3), 947-973.

SAID M. A. \& SHELABY A. A. (2014). Potentials of Egypt agricultural bilateral trade with the Arab countries: Gravity Model Evidence. International Journal of Food and Agricultural Economics. Vol. 2 No. 1 pp.133-144. 
SHEHATA, E. A. (2011). Economic impact for trade between Egypt and COMESA using gravity model of spatial analysis. Egyptian Journal of Agricultural Economics, 20 (4), 1229-1252.

TINBERGEN, J. (1962). Shaping the World Economy: Suggestions for an International Economic Policy. New York, USA: The Twentieth Century Fund.

World Bank, World Development Indicators https://data.worldbank.org/data-catalog/worlddevelopment-indicators, 2017. 